\title{
CHARISSA PFEIFFERI (WEHRLI, 1926) AND OPEROPHTERA FAGATA (SCHARFENBERG, 1805) IN NORTH MACEDONIA (LEPIDOPTERA: GEOMETRIDAE)
}

\author{
Balázs Tóth
}

Hungarian Natural History Museum, Department of Zoology, Baross utca 13, H-1088 Budapest, Hungary (email: toth.balazs@nhmus.hu)

Tóth, B.: Charissa pfeifferi (Wehrli, 1926) and Operophtera fagata (Scharfenberg, 1805) in North Macedonia (Lepidoptera: Geometridae). Nat. Croat., Vol. 29, No. 2., 473-478, 2019, Zagreb.

One Charissa pfeifferi specimen and three specimens of Operophtera fagata were located in the Geometridae material collected by light trap in Prilep, Republic of North Macedonia, between the years 1971 and 1973. These species are considered new for the fauna of North Macedonia.

Key words: Balkan Peninsula, Prilep, Ennominae, Larentiinae, faunistics, genitalia, Hungarian Natural History Museum, light trap, new record

Tóth, B.: Charissa pfeifferi (Wehrli, 1926) i Operophtera fagata (Scharfenberg, 1805) u Sjevernoj Makedoniji (Lepidoptera: Geometridae). Nat. Croat., Vol. 29, No. 2., 473-478, 2019, Zagreb.

Jedan primjerak Charissa pfeifferi i tri primjerka Operophtera fagata pronađeni su u materijalu porodice Geometridae prikupljenom svjetlosnom zamkom u Prilepu, Republika Sjeverna Makedonija, u razdoblju 1971 - 1973. Te vrste smatraju se novima za faunu Sjeverne Makedonije.

Ključne riječi: Balkanski poluotok, Prilep, Ennominae, Larentiinae, faunistika, genitalije, Mađarski prirodoslovni muzej, svjetlosne zamke, novi nalaz

\section{INTRODUCTION}

During the 1970ies a special type of light trap was used in Prilep, a town situated in the southern part of North Macedonia, then part of Yugoslavia (VARGA \& MÉszÁros, 1973). According to Puskás et al. (2015) the light trap was situated at

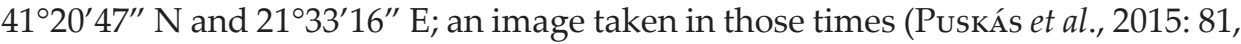
fig. 1b) shows that the trap was operating in a semi-natural or natural environment as the surroundings around were vegetated. However, the coordinates given indicate a site close to downtown of Prilep.

The main goal of the operation was to conduct investigations on migrating Lepidoptera. This resulted in a large amount of material now deposited partly in the Lepidoptera collection of the Hungarian Natural History Museum, but most of the specimens remained in the unidentified and unassigned parts waiting for curation. The single paper regarding the Prilep light trap was written by András Vojnits on vagrant species caught in the years of 1971 and 1972 (Vojnits, 19721973). Faunistic data provided by this trap have hitherto remained unpublished.

In the present paper the data of two species are highlighted, which seem to have faunistic importance: the records of the geometrid moths Charissa pfeifferi (Wehrli, 1926) and Opheroptera fagata (Scharfenberg, 1805) turned to be new for the fauna of North Macedonia. 


\section{MATERIAL AND METHODS}

Geometridae specimens from the material of the Prilep light trap are deposited in the Hungarian Natural History Museum (HNHM), currently placed in six wooden museum drawers, curated according to species but unidentified. The exception is the Geometrinae material which are identified and are incorporated into the main Geometrinae collection. The material is pinned, set and dried; the condition of the specimens varies from poor to excellent due to the specificity of collecting method.

During examination of the material one specimen similar to Charissa intermedia (Wehrli, 1917) and three specimens appearing to be O. fagata were found. The Charissa specimen and an Operophtera specimen were dissected using conventional method (WINTER, 2000), sclerotised structures were stained with eosine.

Adults were photographed with OLYMPUS Camedia C 7070 camera fixed on a stand, genitalia slides were photographed with Olympus DP70 photographic microscope and computer programs DPController and DPManager. Images were adjusted with the program Adobe Photoshop CS2.

\section{RESULTS}

Charissa pfeifferi (Wehrli, 1926)

Material examined: 1 male (Figs 1a, 1b): "Makedonia | Prilep | 1972.IX.6"; slide No. TB1889m.

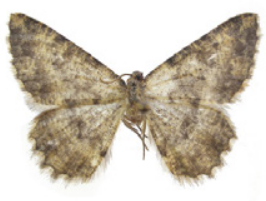

$1 a$
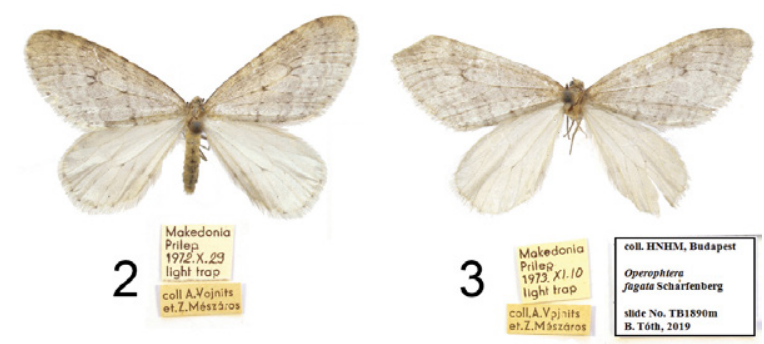

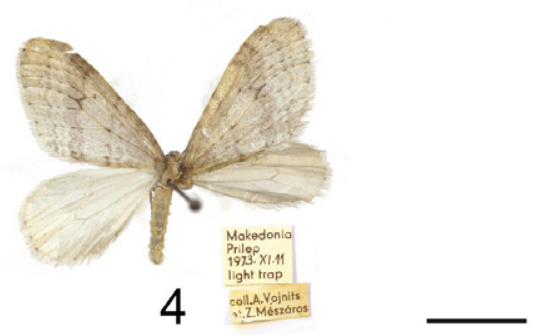

Figs 1-4: adults. Fig. 1a: Charissa pfeifferi (Wehrli), male, upperside ("Makedonia, Prilep"). Fig. 1b: underside of previous specimen and its labels. Figs 2-4: Operophtera fagata (Scharfenberg), male specimens ("Makedonia, Prilep") and their labels. Scale bar: $10 \mathrm{~mm}$, figures are to scale. 
Dissection of the Charissa specimen showed that the specimen represents $\mathrm{Ch}$. pfeifferi (Wehrli, 1926): the wing-like processes on the posterior end of aedeagus are unambiguous characters of this species according to Müller et al. (2019).

Operophtera fagata (Scharfenberg, 1805)

Material examined: 1 male (Fig. 2), "Makedonia | Prilep | 1972.X.29 | light trap I I coll. A. Vojnits | et. Z. Mészáros"; 1 male (Fig. 3), same data but "1973.XI.10"; slide No. TB1890m; 1 male (Fig. 4): same data, but "1973.XI.11".

Identification of $O$. fagata based on the habitus of the specimens was confirmed by the genitalia (Fig. 6): the larger size of the clasping apparatus, the more pointed tip of uncus and the broader saccus, compared to O. brumata (Linnaeus, 1758), were recognisable characters.

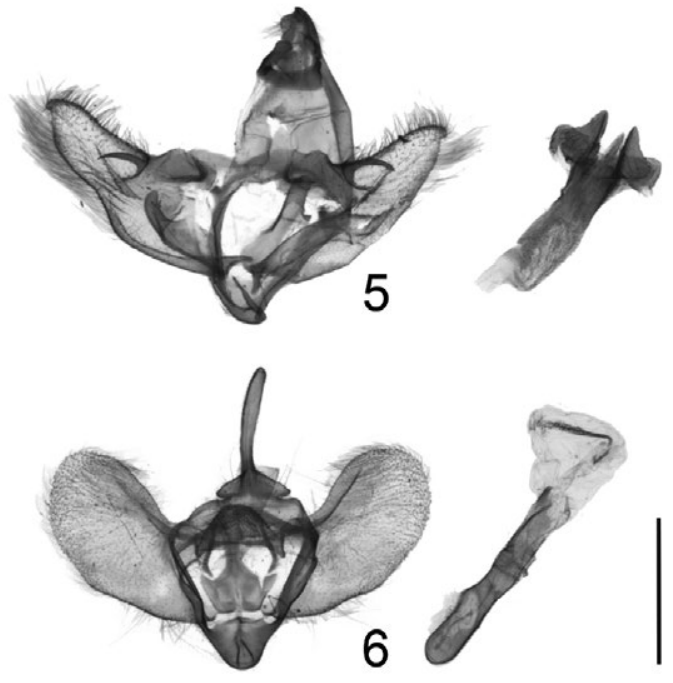

Figs 5-6: male genitalia.

Fig. 5: Charissa pfeifferi (Wehrli) (slide No. TB1889m). Please note that the major part of the chitinous tube of aedeagus remained fixed to the clasping apparatus, only vesica is removed - except for the carinal region (but vesica is still retaining the shape of aedeagus).

Fig. 6: Operophtera fagata (Scharfenberg) (slide No. TB1890m). Scale bar: $1 \mathrm{~mm}$, figures are to scale.

\section{DISCUSSION}

Genus Charissa is a mainly Palaearctic-Oriental genus with one Nearctic species. Species of this genus can be found in diverse warm habitats. Systematics and taxonomy of the genus are still not sufficiently resolved; MüLLER et al. (2019) list 24 European species. Charissa pfeifferi has been hitherto known only from Greece and Bulgaria in Europe; closest record of this species to North Macedonia on the distributional map in MüLler et al. (2019) is at the Strymonian Gulf (Greece). Fauna Europaea (Hausmann et al., 2011) does not treat this taxon at all. The species Ch. pfeifferi occurs in open, uncultivated habitats with rocks; this habitat type is perhaps much more distributed in the Balkan Peninsula than the boreal type of habitat of $O$. fagata. Charissa pfeifferi is externally very similar to Ch. intermedia (Wehrli, 1917), but the apex of forewing is light on underside in the former species while it is dark in the latter one. PINKER (1968) listed Ch. intermedia in his work on the Geometridae of Macedonia but the map in MüLler et al. (2019) does not show any occurrence of this species in the same area. It is possible that "Ch. intermedia" 
of Pinker is actually Ch. pfeifferi but his voucher specimens should be traced and examined to solve this question.

Genus Operophtera is a Holarctic group, preferring deciduous forests, adults occur in cold season. The females are brachypterous. Two species are present in Europe. The distributional map of O. fagata in the book of HAUSMANN \& VIIDALEPP (2012) lacks either any dot or grey area within the borders of North Macedonia: this status means that the authors did not find any specimen in collections and they did not know any literature on that species from that country, respectively. Although occurrence of this species is known from surrounding territories: there is a dot on the border between Albania and Kosovo and a grey area is shown in Bulgaria adjacent to North Macedonia. Status of O. fagata in the Fauna Europaea (Hausmann et al., 2011) is "no data" from North Macedonia. This species is supposed to be local, as its preferred habitat type - beech forests - is scattered in the Balkan Peninsula.

Both species, Ch. pfeifferi and O. fagata, are absent from the overview of PINKER (1968) on the Geometridae fauna of Macedonia. I have not found any literature with published records of either Ch. pfeifferi or O. fagata from this country thus I consider them as new species for the fauna of North Macedonia.

In the recent years several species were recorded in North Macedonia for the first time with exact locality data (e.g. Beshкov, 2017), including such easily recognisable ones as Sphinx pinastri Linnaeus, 1758 (BEshkov, 2019). This is certainly due to the intensification of faunistic exploration for the region, focusing also on night active Lepidoptera.

Recent article shows that material, deposited decades ago in museum collections but remained uncurated, may provide hitherto unpublished records important from faunistic point of view. Therefore, the catalogue of the Geometridae material collected by the Prilep light trap and deposited in the HNHM is planned to be compiled and published in the near future.

\section{ACKNOWLEDGEMENTS}

I express my sincere thanks to Stoyan Beshkov (Sofia) and László Ronkay (Budapest) for faunistic information. I am grateful to Zsolt Bálint (HNHM Budapest) for checking and improving the manuscript with numerous useful comments.

Received September 30, 2019

\section{REFERENCES}

Beshrov, S., 2017: Contributions to the knowledge of the Geometridae fauna of the Balkan Peninsula with some new species for Bulgaria, Serbia, Albania and Macedonia. Atalanta 48 (1-4), 275-290.

Beshкov, S. \& Micevski, N., 2019: Eupithecia gratiosata Herrich-Schäffer, 1861 and Metachrostis dardouini (Boisduval, 1840) new for the Republic of Macedonia. Historia naturalis bulgarica 37, 1-4

Hausmann, A., Viidalepp, J. \& Mironov, V., 2011: Fauna Europaea: Geometridae. In: Karsholt, O. \& Nieukerken, E.J. van (eds.): Fauna Europaea: Lepidoptera, Moths. Fauna Europaea version 2019.09, https://fauna-eu.org

Hausmann, A. \& Vimdalepp, J., 2012: Larentiinae I. In: Hausmann, A. (ed.): The geometrid moths of Europe 3, 1-743. Apollo Books, Vester Skerninge.

Müller, B., Erlacher, S., Hausmann, A., Rajaei, H., Sihvonen, P. \& Skou, P., 2019. Ennominae II. In: 
Hausmann, A., Sinvonen, P., Rajaei, H. \& Skou, P. (eds): The geometrid moths of Europe 6, 1-906. Brill, London.

Pinker, R., 1968: Die Lepidopterenfauna Mazedoniens III. Geometridae. Prirodonaučen Muzej Skopje, Skopje, 158 pp.

Puskás, J., Nowinszky, L. \& MÉszáros, Z., 2015: The beginning of swarming of beetle (Coleoptera) and moth (Lepidoptera) species depending on the lunar phases, in the material of Becse-type lighttrap. e-Acta Naturalia Pannonica 8, 79-90

VARGA, GY. \& MÉszáros, Z., 1973: Combustion products of carbon disulphide for killing mercury light trap catches. Acta Phytopathologica Hungarica 8, 217-222.

Vojnits, A., 1972-1973: Die Wanderfalterausbeute aus den Lichtfallen in Prilep in den Jahren 1971 und 1972 (Lep. Sphingidae et Noctuidae). Atalanta 4, 322-323.

WINTER, W.D. JR., 2000: Basic techniques for observing and studying moths \& butterflies. Memoirs of the Lepidopterists' Society 5, xviii + 444 pp.

\title{
SUMMARY
}

\section{Charissa pfeifferi (Wehrli, 1926) and Operophtera fagata (Scharfenberg, 1805) in North Macedonia (Lepidoptera: Geometridae)}

\author{
B. Tóth
}

During the 1970ies a special light trap was used in Prilep, North Macedonia, to conduct investigations on migrating Lepidoptera. The large amount of material, collected by this light trap, is now deposited partly in the Hungarian Natural History Museum. The Geometridae specimens of the material are currently under revision by the author. Among the specimens Charissa pfeifferi (Wehrli, 1926) and Opheroptera fagata (Scharfenberg, 1805) were found, which turned to be new for the fauna of North Macedonia. The Charissa specimen was identified by genitalia dissection, the identification of three Operophtera specimens as O. fagata based on habitus was confirmed by the genitalia. Charissa pfeifferi is a very local species in Europe with insufficiently known habitat preference, while Operophtera fagata is much more widely distributed and its habitat needs are more understood than in the previous species. 
